\title{
THE ETHNOBOTANY OF SWEET FLAG AMONG NORTH AMERICAN INDIANS
}

\author{
George R. Morgan*
}

The aromatic arum commonly known as Sweet Flag (Acorus Calamus L. of the Araceae) is an ancient and widely used medicinal plant. The plant's pungent-tasting rhizomes have been utilized as a medicine for many kinds of ailments, especially those relating to the respiratory and digestive systems. Also, many peoples have used the rhizomes as a tonic and stimulant, particularly Indian tribes of the western interior of North America. European peoples have employed the rhizomes as a flavoring agent in liquors, gin, beer and ice cream; they have also utilized the plant in perfumes, snuff and hair powder. New Englanders still continue to sugar and slice rhizomes for confectionary. Southern blacks used the rootstocks as a condiment; their consumption of the plant was mentioned in the classic folklore stories of "Uncle Remus" (Harper, 1936). Plains Indians were said to attribute mystic powers to Sweet Flag (Gilmore, 1919); the Pawnee mystery ceremonies included songs about Sweet Flag (Gilmore, 1919). In North Dakota, Calamus was used by Siouan shamans in a "holy dance" (wakan wacipi) (Howard, 1953).

Although the plant is usually called Sweet Flag, many other common names call attention to the sweet-smelling aerial stems or the aromatic rhizomes: Sweet Cane, Sweet Grass, Sweet Myrtle, Sweet Rush, Sweet Sedge, or Sweet Root. In 1860, Henry David Thoreau described the plant as having as agreeable and "peculiar frangrance" (Thoreau, 1860).

The aromatic stems and leaves of Sweet Flag inspired Walt Whitman to write a set of thirty-nine poems known as the "Calamus poems," which he included in his Leaves of Grass (3rd ed., 1860). Scented Calamus was strewn on church floors in

*Visiting Scholar in Ethnobotany, Botanical Museum, Harvard University (1980). Present address: Chadron State College, Geography Department, Chadron, Nebraska. 
sixteenth century England, and the plant was commonly spread on the floors of homes in colonial New England. The identifying scent has been helpful in distinguishing it from the poisonous Blue Flag (Iris versicolor L.). a marshy plant that resembles Sweet Flag in its vegetative stage.

The plant's widespread use among peoples of both the Old and New World is due partly to its cosmopolitan range in the Northern Hemisphere on the continents of Asia, Europe and North America. Although Acorus Calamus is a gregarious semiaquatic plant restricted in habitat to the margins of fresh and brackish waters - swamps, marshes, bogs, ponds and rivers - it is able to live in a variety of climatic zones ranging from the tropics to the sub-arctic. The plant grows most abundantly, however, in the North Temperate Zone.

Man has increased the geographic range of Acorus Calamus. It was not native to Europe. European populations of Acorus Calamus do not bear fertile fruit: they remain sterile triploids $(2 n=36)$ and propagate vegetatively by rhizomes. The nomadic Tartars had introduced the plant into European Russia by the thirteenth century (Buell, 1935); the "Mongolian Dragon" also introduced the plant into eastern Europe (Buell, 1935). According to Murray Buell, Tartars brought Acorus Calamus on the steppes of Russia because they drank water only when macerated with the rhizomes (Buell, 1935). Rhizomes were also introduced from southern Asia via Constantinople (Istanbul) into central Europe during the mid-sixteenth century (Mücke, 1908).

Most populations of Acorus Calamus east of the Appalachians are sterile. Some authorities believe that early seventeenth century colonists introduced it to the eastern seaboard from Europe. Experiments have shown that some populations in the Northeast are able to reproduce by seed; sterile clones may have resulted from selected rhizomes planted by colonists for medicinal and confectionary uses (Jervis and Buell, 1964). Possibly, the species is represented by both native and introduced strains along the Atlantic seaboard.

Populations of Sweet Flag in the interior of North America are fertile diploids $(2 \mathrm{n}=24)$, but Melvine R. Gilmore, a noted ethnobotanist, was unsuccessful in finding seed-producing 
plants in the Central Plains (North Dakota to Oklahoma). He speculated that Indian medicine men planted Sweet Flag in the interior, observing that the plant was highly valued among Indian tribes, such as the Pawnee of Nebraska; and he commonly found the plant near former Indian village sites or near camping places along old Indian trails (Gilmore, 1931). In the early 1970's, Richard Full Bull, a Sioux, showed Kay Young an area of Sweet Flag on the Rosebud Reservation in south-central South Dakota. Full Bull claimed that his father had planted it there about 1900 (Young, 1980). An elderly Oglala Sioux, born in 1896, remembers that when her grandmother was alive (nineteenth century) some roots of Sweet Flag were transplanted to her reservation (Pine Ridge) in southwestern South Dakota from St. Charles in eastern South Dakota (Yankton Sioux country) (Chief, 1980). Although today Sweet Flag is rarely found growing at Pine Ridge, the roots are said to be more bitter and stronger than roots from eastern South Dakota (Chief, 1980). The Oglala Sioux obtain most of their supply of Sweet Flag from Siouan tribes of central and eastern South Dakota, notably the Brule, Santee, Yankton and Sisseton.

The inter-tribal trade price of the plant is rather high: an Oglala Sioux payed as much as $\$ 5.00$ for a piece of root two inches in length (Good Shield, 1980). The Northern Cheyenne of Montana have also obtained the roots of Sweet Flag from the Sioux (Grinnell, 1923).

The muskrat (Ondatra zibethica), a ubiquitous semiaquatic rodent native to North America, might have played an important role in the propagation of Sweet Flag. The muskrat has a voracious appetite for the plant, especially for its rhizomes. The animal's eating habits may have increased the geographic range of the plant. When food is abundant, the muskrat is wasteful; scraps of plant parts are left behind on "feeding platforms" (Takos, 1947). The Canadian biologist, Michael Sarrazin, who pioneered in anatomical studies of the muskrat, believed that the special musky odor from the musk glands resulted from the animal's abundant nourishment of Acorus Calamus (Vallée, 1927).

Muskrat furs constituted an important trade item for the Indian. The fecund muskrat was an economic mainstay of the 
Hudson Bay Company (1670-1873); the dyed and plucked fur, known as "Hudson seal," increased the animal's value. Although the beaver pelt was the most prized, it was exhaustible. Female beavers bear annually only one litter of four. By contrast, the female muskrat is prolific, able to produce up to five litters a year, each litter normally with eleven offspring (Ray, 1975).

Hudson's Bay Territory was largely conterminous with Canada's Laurentian Shield, a boreal forest country with hundreds of fresh water lakes, an ideal habitat for Sweet Flag and the muskrat. Much of this vast wilderness was the territorial hunting land of Algonquian tribes, especially of the Cree and Ojibway.

While on long hunting expeditions, the Cree chewed Sweet Flag rhizomes as a stimulant against fatigue and for endurance. In 1892, R. Strath visited Norway House, a former fur trade centre of Hudson Bay Company, located about 400 miles north of Winnipeg. His observations of the plant among the Cree are interesting:

Large bundles of this plant can be seen hanging in every tepee or wigwam, tent or house wherever Indians are found, and seems to be the family medicine of the people, its virtues being known to all.... A piece of root is carried by every tripper on his hunts and trips for the Hudson Bay Company and when feeling exhausted by hunger or fatigue, a small piece slowly chewed will restore the flagging energies in a most wonderful manner (Strath, 1903).

The Indian may intentionally have propagated Acorus Calamus not for medicine alone but to insure a future supply for the muskrat upon which their livelihood depended. Thus, the fur trapping Indian, the muskrat, and Sweet Flag may have constituted a complementary interlocked ecologic system in the northlands.

Extending across an immense territory, from maritime Canada and New England to the upper Great Lakes, Alberta and the Dakotas, the plant was named after the muskrat by several Indian tribes. The word muskrat originates from the Algonquin word musquash (Natick dialect). The following tribes have called the plant "muskrat root" or "muskrat food": Algonquian language stock - the Abnaki of New Brunswick and Maine, moskwas'wask (Rousseau, 1946-48); Micmac-Montagnais of Newfoundland, ki we swask (Speck, 1917); Penobscot of Maine, muskwe s uwesk (Speak, 1917); Cree near Hudson Bay, weekas 


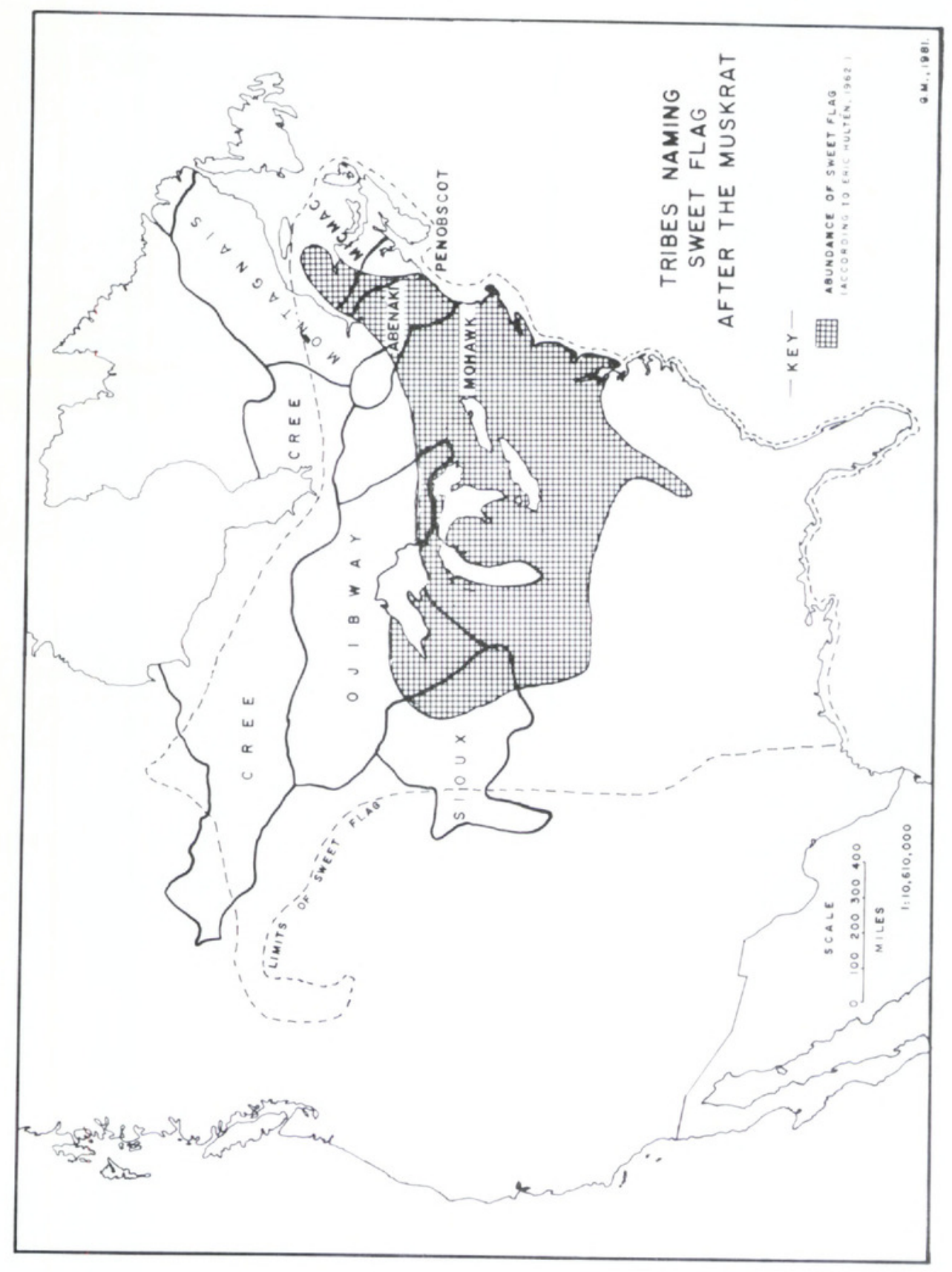


(Strath, 1903), wekas (Flexon, 1897-1898), and watchuske mitsu in, "that which the musk rat eats" (Franklin, 1854); Chippewa (Ojibway) of Minnesota-Ontario, wiken (Densmore, 1928), and Chippewa of Ontario-Michigan, wika (Gilmore, 1933); Iroquoian language stock - the Mohawk of New York State, anotion ao-titara (Rousseau, 1945); Siouan language stock-the Dakota Sioux, Minnesota and the Dakotas, $s i^{\mathrm{n}} k p e$-ta-wote (Gilmore, 1919).

A Penobscot Indian dreamed that the "muskrat spirit" was the "muskrat root":

The muskrat told him that he was a root and where to find him. The man awoke, sought the muskrat root, made a medicine of it, and cured the people of the plague. (Speck, 1917).

The Penobscot believed that they would be cured of cholera by utilizing Sweet Flag; observing that muskrats eating the plant had meager excrements, they believed that the effects would be the same for them (Speck, 1917).

The occurrence of the name "muskrat root" or "muskrat food" among different tribes of three language families strongly suggests diffusion. The fact that these tribes were contiguous strengthens the case for diffusion. Furthermore, Europeans may have aided in the dissemination of the animal's name in the fur trade, the British calling the animal musquash (later muskrat), the French using the term rat musque.

Sweet Flag has been considered a panacea medicine among culturally diverse Indian tribes, such as the Cheyenne, Dakota, Micmac and Mohegan. Many tribes have employed Acorus Calamus as an expectorant and febrifuge for curing the common cold. The Chippewa snuffed Sweet Flag for colds (Densmore, 1928). For colds and bronchial problems, the Chippewa also mixed Sweet Flag with the bark of Xanthoxylon americanum Mill., bark roots of Sassafras variifolium (Salisb.) Ktze., and the roots of Asarum canadense L. (Gilmore, 1933). For colds, the Dakota, Omaha, Winnebago and Pawnee chewed the root or made an infusion (Gilmore, 1919); for colds, they also used the smoke treatment - breathing fumes of the plant under a blanket from the root shavings or powder sprinkled on live charcoals. Among the Swampy Cree, Sweet Flag has been an important medicine for curing various throat troubles: 
It is considered a specific in all throat troubles .... In the case of pharyngitis it is used externally and internally. The rhizome is chewed and the saliva allowed to wash the throat. Poultices are made by mixing the powder with boiling water. (Flexon, 1897).

Among the Iroquois, Sweet Flag has been valued as an aid for singing at ceremonials or pow-wows (Fenton, 1942). The Sioux still use Sweet Flag when they sing at ceremonials or pow-wows (Elk Boy, 1979; Primeaux, 1979). They place a small piece of the root in the mouth; the juices of the root are said to keep the throat clear while singing. Sweet Flag was also used by Europeans to clear the throat:

When the rhizome is masticated, it is said to clear the voice, and it is sold by herbalists for this purpose ... (Bentley, 1880).

Indians, especially those of hunting cultures, employed Sweet Flag as a carminative, emetic and cathartic for relief of gastrointestinal discomforts. For example, the Abnaki of New Brunswick drank a warm decoction of Sweet Flag as a carminative to relieve stomach gas (Rousseau, 1946-1948). Because of irregular eating, due partly to dietary customs as well as lack of food, intestinal problems were common among peoples of the hunting economy:

Digestive disturbances were frequent due to two conditions. First, spells of semi-starvation alternated with periods of abundance, during which they grossly overate. Second, it was the custom on hunting and war parties, or when the village was moving through hostile country, to abstain from food, not infrequently for several days at a time. These fasts were broken by an orgy of feasting (Stone, 1932).

The diet and eating habits of the contemporary Indian are generally poor. The prevalence of alcoholism is a major cause of semi-starved families; the diet is largely one of greasy food. Among the Sioux, for example, Sweet Flag is still commonly used to relieve gastro-intestinal disturbances.

Acorus Calamus was commonly employed as an analgesic. Several tribes applied Sweet Flag as toothache medicine, notably the Cree (Osmund, 1967), the Chippewa (Densmore, 1928), and the Sioux, Omaha, Pawnee, and Winnebago (Gilmore, 1919). The Cree also valued the plant to relieve headaches (Osmund, 1967); Resident Nurse, 1943); the Sioux breathed in 
the burned fumes of the plant to cure headaches (Bear Killer, 1980; Lame, 1981).

Cree women were known to use an infusion of Acorus Calamus tea for the discomfort of dysmenorrea (Strath, 1903). Among the Winnebago, women mixed Sweet Flag (man' $a^{\text {n }}$ kera' xera) with six other plants in water; when thoroughly mixed, the preparation was injected into the bladder with a wing bone (Radin, 1923).

Oklahoma Delaware women used the rhizome to suppress menses (Tantaquidgeon, 1942). Menominee women ground the rhizome with bloodroot (Sanguinaria canadensis L.) and pieces of cedar wood as a remedy for irregular menstruation (Densmore, 1932). The Blackfoot of western Montana are said to have employed Sweet Flag to cause abortion (Johnston, 1970).

Several tribes have used Sweet Flag as an external medicine. The Meskwaki rubbed the plant on burns (Smith, 1928). An elderly Sioux rubbed the plant on sores or places where the body hurts: "People also put it on an open sore and then bandage it" (Left Hand, 1980). An eighty-year-old Sioux woman claimed that she relieved the effects of a stroke by rubbing her face with a salve of Sweet Flag and grease (Good Shield, 1980).

Sioux warriors chewed rhizomes to a paste which they smeared on their face to prevent fear in the presence of the enemy (Gilmore, 1919). But the juice swallowed by the warriors was perhaps more important for their needs than the smear of facial paste. At the battlefront, descendents of Sioux warriors chewed the plant in both World Wars and in the Korean and Viet Nam conflicts; it was thought to instil fearlessness and enhance endurance (Bear Killer, 1979). A Sioux indicated that muskrats are fierce and "afraid of nothing" because the animal eats Sweet Flag; thus, the plant would make a man fearless (Bear Killer, 1979).

The Sioux administered Sweet Flag to dogs to make them fierce watchdogs. They would give a puppy an infusion of tea from a boiled root or spit the masticated root of the plant into the puppy's mouth; after doing this two or three times, the puppy would grow up to be "mean" and a good watchdog protecting the family (Bear Killer, 1979; Good Shield, 1980). 
The Cheyenne and the Sioux considered Sweet Flag to be an amulet. To keep away night spirits, Cheyenne children had a piece of the root tied to their necklet or blanket (Grinnell, 1923). The Sioux used the "smoke treatment" to "chase away ghosts" (Bull Man, 1980). An elderly Sioux woman gave an interesting account of Sweet Flag being utilized to drive away evil spirits:

My grandmother's son lived in a haunted house. He locked the door but it would open at night and there would be a strong wind even though it was quiet outside. Fifty years ago my grandmother told me that it (Sweet Flag) was good for haunted houses. Grind up the root and burn and smoke all the rooms to drive away spirits. My son did it and it worked. The door never opened again. (Chief, 1980).

Even today, many elderly Sioux carry a piece of the rhizome with them as an amulet.

Some tribes not only took Sweet Flag as a tonic for themselves but would give it to horses to make them spirited and run faster. The Omaha gave the plant as a snuff to horses (Grant, 1980); the Oglala and Yankton Sioux administered an infusion of Sweet Flag to race horses (Elk Boy, 1979; Primeaux, 1979). When Peyote (Lophophora williamsii (Lem.) Coult.) was adopted by the Yankton Sioux in the earlier part of this century, however, they gave their race horses an infusion of Peyote (Primeaux, 1979).

Smith reported an unusual use of Acorus Calamus by a Flambeau Ojibwe Indian, Big George, who soaked a gill net in an infusion of Sweet Flag and Sarsaparilla to make a "fine catch" of white fish (Smith, 1932); Smith relates that the fish net "still smelled of Calamus root after being in the water more than twelve hours..." (Smith, 1932).

An informant of Hoffer and Osmund, who lived among the Cree of northern Alberta, experimented with large doses of Sweet Flag. On five different occasions, the informant and his wife chewed ten inches of the rhizome; each time, they had an experience similar to that induced by LSD (Hoffer and Osmund, 1967). Since both the informant and his wife (a psychiatric nurse) had taken LSD several times under controlled conditions, they were perhaps preconditioned physiologically and psychologically to have such a similar experience. The quantity that each 
informant had taken was ten times the amount normally taken by the Cree for anti-fatigue (Hoffer and Osmund, 1967). Sweet Flag may be hallucinogenic in larger quantities: Indians possibly took the plant for that purpose, since they were careful to consume only small quantities when it was used as a medicine. The prescribed amount of the rhizome eaten by the Chippewa was the length of an index finger (Densmore, 1928); Smith reported that the Chippewa took no more than one and a half inches (Smith, 1932); the Forest Potawatomi were "cautious" of the amount they used, believing that only a "very small piece" was necessary (Smith, 1933); the Menomini consumed no more of the rhizome than the length of a finger joint, because they considered the plant to be a powerful medicine (Smith, 1923); the amount taken by an adult Cree in a mid-nineteenth-century report was about the "size of a small pea" (Franklin, 1854). If the plant is proven to be hallucinogenic, it is quite possible that earlier generations of Indians knew of that effect and that later generations lost the knowledge. Indians of former times may have known that larger amounts of the plant would alter states of consciousness. To date, chemical investigations suggest that $\alpha$-asarone and $\beta$-asarone are the active principals in Sweet Flag. Although mescaline and asarone are structurally similar, their biological effects differ; asarone is not known to be truly hallucinogenic (Schultes and Hofmann,1980).

Sweet Flag continues to be an important medicinal plant among various Indian tribes, although it is now more often used by the older generation. The revival of interest in the preservation of traditional ways of life, as shown by the younger Indians within the last decade, perhaps insures a continued use of the plant as a medicine.

\section{BIBLIOGRAPHY}

Bear Killer, Ralph. Chadron, Nebraska. Interview with Morgan. 1979-80. Bentley, Robert and Henry Trimen. 1880. Medicinal Plants, 4, J. \& A. Churchill, London.

Buell, Murray F. 1935. "History and Uses of Calamus." The American Botanist, 41, 51-55., 1935.

Bull Man, Thomas. Porcupine, South Dakota. Interview with Morgan. 1980.

Chief, Helen. Pine Ridge, South Dakota. Interview with Father Paul J. Steinmetz, S.J., Ph.D., 1980. 
Densmore, Frances. 1928. "Uses of Plants by the Chippewa Indians." Forty-fourth Annual Report of the Bureau of American Ethnology, 1926-1927, U.S. Government Printing Office, Washington, 1928. Reprint: How Indians Use Wild Plants, Dover Publications, New York, 1974.

Densmore, Frances. 1932. "Menominee Music." Bulletin of the Bureau of American Ethnology, 102, Washington, D.C.

Elk Boy, Ira. Chadron, Nebraska. Interview with Morgan. 1979.

Fenton, W.N. 1941. "Contacts Between Iroquois Herbalism and Colonial Medicine." Annual Report of the Borad of Regents of Smithsonian Institution, 503-526. Washington, D.C.

Flexon, C. 1897-1898. "Some Medicines of the Swampy Cree Indians of the North.” Pharmaceutical Journal and Gazette, 31, 126-129. Toronto, Canada.

Franklin, Sir John. 1854. Arctic Searching Expedition: A Journal of a Boat-Voyage Through Ruperts Land and the Arctic Sea. Harper and Brothers, New York.

Gilmore, Melvin R. 1919. "Uses of Plants by the Indians of the Missouri River Region." Thirty-third Annual Report of the Bureau of American Ethnology. Reprint: Bison Books, University of Nebraska Press, 1977, Lincoln, Nebraska.

Gilmore, Melvin R. 1931. "Dispersal by Indians a Factor in the Extension of Discontinuous Distribution of Certain Species of Native Plants." Papers of the Michigan Academy of Science, Arts and Letters, 31, 89-94, 1931. Ann Arbor, Michigan.

Gilmore, Melvin R. 1933. "Some Chippewa Uses of Plants." Papers of the Michigan Academy of Science, Arts, and Letters, 17, 119-143. New York.

Good Shield, Helen. Porcupine, South Dakota. Interview with Morgan. 1980.

Grant, Alice. Macy, Nebraska. Interview with Morgan. 1980.

Grinnell, George Bird. 1923. The Cheyenne Indians, their History and Ways of Life, vol. 2, Yale University Press. Reprint: Bison Books, University of Nebraska Press, Lincoln, Nebraska, 1972.

Harper, Roland M. 1936. "Is Acorus Calamus native in the United States?" Torreya, 36, 143-147, Dec. 1936.

Hoffer, A. and H. Osmund. 1967. The Hallucinogens. Academic Press, New York.

Howard, James. 1953. "Notes on Two Dakota 'Holy Dance' Medicines and Their Uses.” American Anthropologist, 55, 608-609, 1953.

Hultén, Eric. 1962. The Circumpolar Plants, vol. 1, Almqvist and Wiksell, Stockholm.

Jervis, Robert A. and Murray F. Buell. 1964. "Acorus Calamus in New Jersey." Torreya, 91, 335, 1964.

Johnston, Alex. 1970. "Blackfoot Indian Utilization of the Flora of the Northwestern Great Plains.” Economic Botany, 24, no. 3, 301-323.

Lame, Fannie. Chadron, Nebraska. Interview with Morgan. 1981.

Left Hand, Andrew. Pine Ridge, South Dakota. Interview with Father Paul J. Steinmetz, S. J., Ph.D, 1980. 
Mücke, M. 1908. "Über den Bau und die Entwicklung der Fruchte und über die Harkunft von Acorus Calamus L." Botanische Zeitung, 66, $1-23,1908$.

Primeaux, Asa. Marty, South Dakota. Interview with Morgan. 1979.

Radin, Paul. 1923. The Winnebago Tribe. Thirty-Seventh Report of the Bureau of American Ethnology, Smithsonian Institution, Washington, 1923. Reprint: Bison Books, University of Nebraska Press, Lincoln, Nebraska, 1970.

Ray, Arthur J. 1975. "Some Conservation Schemes of the Hudson's Bay Company, 1821-50: An Examination of the Problems of Resource Management in the Fur Trade." Journal of Historical Geography, 1, no. 1, 49-68, Academic Press, New York.

Resident Nurse. 1943. "Medicine Man.” The Beaver. June, 1943.

Rousseau, Jacques. 1945. "Le Folklore Botanique de Caughnawaga." Contributions Institute Botanique Université, 55, 7-74, 75-111, Montréal.

Rousseau, Jacques. 1946-1948. "Notes sur l'Ethnobotanique Abénakise (2); Ethnobotanique et Ethnozoologie Gaspésiennes (3); paper no. 2" Memoires du Jardin Botanique de Montréal, Jardin Botanique de Montréal, Canada.

Schultes, Richard Evans and Albert Hofmann. [Ed. 2] 1980. The Botany and Chemistry of Hallucinogens. Charles C. Thomas, Springfield, Illinois.

Smith, Huron H. 1923. "Ethnobotany of the Menomini Indians." Bulletin of the Public Museum of the City of Milwaukee, 4, no. 1, 1-174, 1923.

Smith, Huron H. 1928. "Ethnobotany of the Meskwaki Indians." Bulletin of the Public Museum of the City of Milwaukee, 4, no. 2, pp. 175-326.

Smith, Huron H. 1932. "Ethnobotany of the Ojibwe Indians." Bulletin of the Public Museum of the City of Milwaukee, 4, no. 3, 327-525, 1932.

Smith, Huron H. 1933. "Ethnobotany of the Forest Potawatomi Indians," Bulletin of the Public Museum of the City of Milwaukee, 7, no. 1, 1-230, 1933.

Speck, Frank G. 1917. "Medicine Practices of the Northeastern Algonquians." Extract from Proceedings of the Nineteenth International Congress of Americanists, Washington, D.C. December, 303-321, Washington, D.C.

Stone, Eric. 1932. Medicine Among the American Indians. Paul B. Hoeber, Inc. New York, 1932.

Strath, R. 1903. "Materia Medica, Pharmacy and Therapeutics of the Cree Indians of the Hudson Bay Territory." The St. Paul Medical Journal (October, 1903) 5, 735-746, St. Paul, Minnesota.

Takos, Michael J. 1947. "A Semi-Quantitative Study of Muskrat Food Habits." Journal of Wildlife Management, 11, no. 4, 331-339 (October) 1947.

Tantaquidgeon, G. 1942. A Study of Delaware Indian Medicine Practices and Folk Beliefs, Harrisburg, 1942.

Thoreau, Henry D. 1860. (May 23). The Journal of Henry D. Thoreau, Houghton Mifflin Company, Boston, 1949.

Vallee, Arthur. 1927. Un Biologiste Canadien, Michel Sarrazin, 1659-1735, Sa Vie, ses Travaux et son Temps. Quebec.

Whitman, Walt. 1860. Leaves of Grass. Thayer and Eldridge, Boston.

Young, Kay. Chadron, Nebraska. Interview with Morgan. 1980. 


\section{$2 \mathrm{BHL}$ Biodiversity Heritage Library}

Morgan, George R . 1980. "The Ethnobotany of Sweet Flag Among North American Indians." Botanical Museum leaflets, Harvard University 28(3), 235-246. https://doi.org/10.5962/p.168647.

View This Item Online: https://www.biodiversitylibrary.org/item/31875

DOI: https://doi.org/10.5962/p.168647

Permalink: https://www.biodiversitylibrary.org/partpdf/168647

\section{Holding Institution}

Missouri Botanical Garden, Peter H. Raven Library

\section{Sponsored by}

Missouri Botanical Garden

\section{Copyright \& Reuse}

Copyright Status: Public domain. The BHL considers that this work is no longer under copyright protection.

This document was created from content at the Biodiversity Heritage Library, the world's largest open access digital library for biodiversity literature and archives. Visit BHL at https://www.biodiversitylibrary.org. 